\title{
12
}

\section{Global Value Chains and Upgrading in Economic Community of West African States Countries}

\section{Anani Nourredine Mensah and Abdul-Fahd Fofana}

\subsection{Introduction}

In an increasingly interconnected global economy, where over $70 \%$ of trade is in intermediate goods and services, integration into global value chains $(G V C s)$ today will determine future trade and FDI patterns, as well as growth opportunities. ${ }^{1}$

Indeed, since the 1990s, global trade has undergone drastic changes. The falling transport and communication costs, coupled with technological advances and trade liberalization, have profoundly transformed the way goods and services are produced.

A. N. Mensah $(\bowtie)$

University of Lome, Lome, Togo

A.-F. Fofana

Center for Research and Training in Economics and Management, Lome, Togo 
As a result, competition has increased and firms have been forced to review their organizational pattern and method of production (Porter 1986; Lorenzi 2005). For the most part, firms have expanded geographically in a given form (offshoring, outsourcing, etc.) in an effort to capture growth opportunities and competitive benefits; hence the emergence of what is known as GVCs. GVCs describe a decentralized and interconnected process, covering activities from the conception and design stages to manufacturing, marketing and commercialization of goods and services (Gereffi and Fernandez-Stark 2011).

This principle of fragmentation of production processes is the culmination of previous contributions relating to specialization and the international division of labour. It draws its inspiration from both the theory of international trade (Smithian and Ricardian theories and the Heckscher-Ohlin-Samuelson models, known as HOS for short) and the industrial economy approach (Porter and Competitive Advantage 1985).

This new configuration of world trade offers fresh opportunities and possibilities for structural change in developing countries, which are no longer forced to set up entire production units (Baldwin 2012; Escaith 2014) but can now fit themselves in as links in a GVC, depending on their comparative advantages, while benefiting from transfers of foreign skills and know-how (Hausmann et al. 2014).

As new avenues of economic growth, GVCs are certainly opening up new opportunities but are not by any means a panacea. For a firm to actually reap the benefits of participating in a GVC, its participation must go in tandem with the upgrading of its activities. ${ }^{2}$ GVCs have been well documented, and their effects are the subject of many recent empirical studies. Nevertheless, few studies have been carried out on upgrading.

Humphrey (2004) conducted an analysis of upgrading in the agricultural and manufacturing sectors of a sample of developing countries. It revealed that participation in a GVC positively affects the technological capacity and the upgrading of economies. Rodrik (2006) tested the same assumption in China using a methodology based on sophistication measurement and found that participation in the GVC contributed significantly to the sophistication of Chinese exports. In the case of India, Felipe Jesus et al. (2012) also analysed upgrading in the GVC through export 
sophistication and diversification. They clearly showed that India's exports are well diversified and sophisticated. Bernhardt and Milberg (2011) also analysed upgrading in certain sectors (horticulture, clothing, mobile phones and tourism) of the GVC. The results highlight the existence of upgrading, with the exception of the clothing sector.

This issue has been well documented in the case of African countries. However, worth mentioning is Hidalgo (2011) who analysed upgrading in East African countries. Using the concept of product space to analyse export diversification and sophistication, he found that these countries, with the exception of Kenya, generally have poorly diversified and unsophisticated exports (all of which are located on the periphery of the product space). By measuring export sophistication, Hausmann et al. (2014) showed that exports from Uganda are poorly diversified and unsophisticated. Similar findings were made by Abdon and Felipe (2011) and Hausmann and Jasmina (2015) respectively in sub-Saharan Africa and Rwanda.

The objective of this chapter is to analyse the upgrading of African countries (especially those of Economic Community of West African States [ECOWAS]) in the GVC. This choice was motivated by two main reasons. First, West Africa is one of the most open regions in the world. However, it must be said that the region's share of international trade remains below its potential and represents $0.7 \%$ in value of world exports, compared with $0.5 \%$ of imports. ${ }^{3}$ Moreover, in terms of upgrading, these countries have lagged behind other regional groups, which seems to suggest that the openness has contributed little to improving economic performance. Hence, the question of whether or not the position of its States in trade allows them to benefit from their integration in the world economy. Second, in 2014, these countries concluded negotiations on the Economic Partnership Agreement (EPA) with the European Union, which have led to the promotion of integration into the GVC. This justifies the choice of this zone where there are few empirical studies on the GVC theme.

This chapter is divided into three sections: (1) the first section defines GVC and upgrading concepts; (2) the second section analyses the level of participation of ECOWAS countries in the GVC; and (3) the last section analyses the upgrading of countries of the community. 


\subsection{Definition of the GVC and Upgrading Concepts}

\subsubsection{GVC Concept}

In recent years, there has been a shift from trade that helps to "sell" goods to trade that helps to "make" goods (Baldwin et al. 2014). This phenomenon, formalized by the expression "global value chains", may also be comprehensible under the terms "global supply chains", "international production networks", "vertical specialisation", "outsourcing" and "production fragmentation".

The GVC concept is promoted by Porter (1986) who describes it as a set of interdependent and coordinated activities allowing the creation of identifiable and measurable value if possible. The value chain encompasses all backward and forward activities leading to the production of a product or service (Porter 1986). A GVC refers to when these activities are fragmented across sites and borders (Lunati 2008).

It also refers to the full range of activities which are required to bring a product or service from design through the various phases of production and delivery to final consumers and final disposal after use (Kaplinsky 2004).

GVCs refer to the interconnected production process that goods and services undergo from conception and design through production, marketing and distribution (Gereffi and Fernandez-Stark 2011).

In this research, we have adopted the simple notion proposed by Lunati (2008) and which seems to capture the meaning of most of the above definitions. According to Lunati, GVCs are international supply chains characterized by fragmentation of production activities across sites and borders.

\subsubsection{Upgrading Concept}

A company is upgraded in the GVC to which it already belongs when it creates more value added (Gereffi et al. 2001). In a value chain, various types of upgrading may be distinguished (Humphrey and Schmitz 2000): 
"process upgrading", "product upgrading”, "functional upgrading” and "chain upgrading".

- "Process upgrading" takes place when there is an improvement in the production process, allowing more efficient transformation of inputs into outputs. The company is therefore able to perform tasks in a more efficient way and with a lower imperfection rate than its competitors.

- "Product upgrading" takes place when the company can introduce new products, modify the design, improve the quality and supply an end product that has a higher value added by virtue of its higher level of sophistication.

- "Functional upgrading" occurs when other stages of production in the GVC can be accessed. In this case, the company is able to offer competitive products with greater value added. This means that changes are made upstream and downstream of the production process.

- "Chain upgrading" or "inter-chain upgrading" corresponds to movement from one industry to another. It thus occurs when a company is able to refocus or position its activities in new GVCs with higher value added. Very often, greater integration into the GVC is also referred to as "institutional upgrading".

A company can then upgrade in the GVC either by optimizing the value of its supply, developing a strategy for adding services to its range of products, or by implementing a customer strategy through stronger relationships with its clientele (Lahille et al. 1995).

\subsection{GVC Participation}

\subsubsection{GVC Participation Measurement}

To measure a country's participation in the GVC, it is necessary to know the sources and destinations of the value added of the products. Two indicators are usually used to measure a country's GVC participation: the "backward integration" index and the "forward integration" index. 
Backward integration measures the share of inputs imported by a country and used in local production for export purposes, or the share of foreign value added (FVA) incorporated in a country's exports. Forward integration measures the share of domestic value added (DVA) in exports from other countries. The GVC participation index is the sum of these two indicators expressed as a percentage of gross exports (Koopman 2011).

\subsubsection{Level of Participation of ECOWAS Countries in the GVC}

Africa accounts for a modest but growing share of value-added trade (from $1.4 \%$ in 1995 to $2.2 \%$ in 2011). ${ }^{4}$ West Africa is the third-best region in Africa in terms of GVC integration, but the integration is strongly driven by forward integration. With just under USD 40 million in 2011, West Africa accounts for about 15\% of Africa's GVC participation, with only a quarter being backward integration (Fig. 12.1).

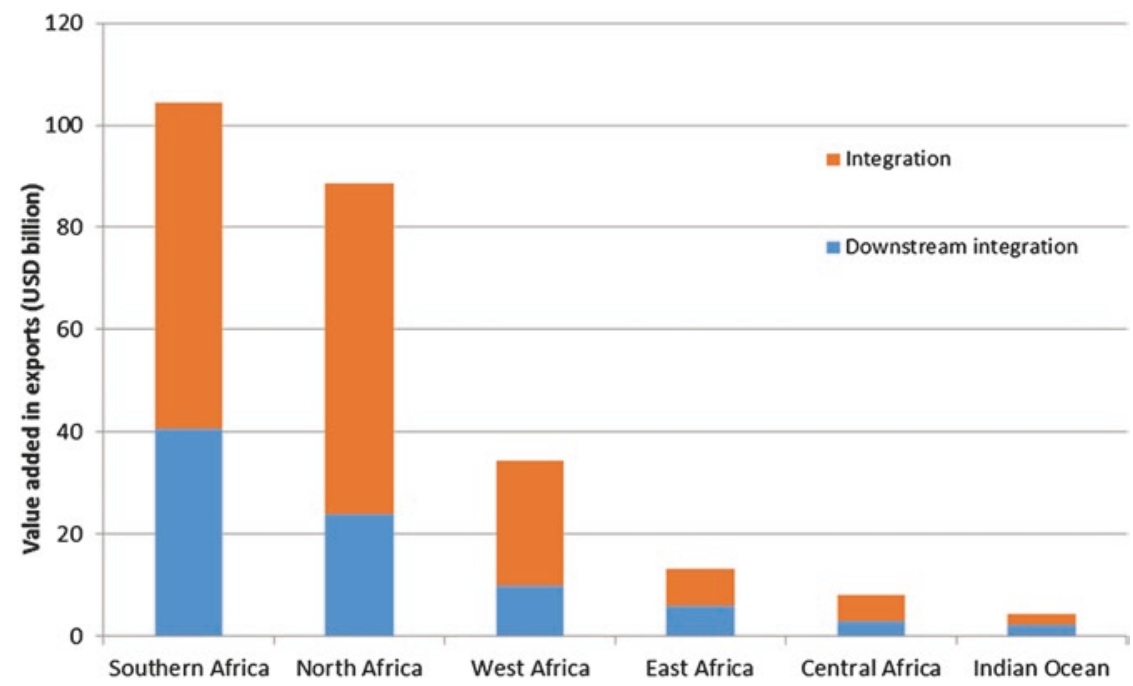

Fig. 12.1 Integration of African regions in GVCs, 2011. Source: Authors' elaboration based on AfDB et al. (2014) (from UNCTAD-EORA-GVC data) 
Europe and Asia are the continents with which ECOWAS trade most in terms of value added. West African inputs in the GVC (Fig. 12.2) are mainly destined for Europe and Asia, which respectively absorb 60\% and $12 \%$ of West African products integrated downstream of the value chain. Regarding backward integration, Europe is also West Africa's leading supplier (Fig. 12.3), with a share of around $40 \%$. Asia comes second with a share of about $32 \%$.

Figures 12.4 and 12.5 illustrate the FVA incorporated in the exports of ECOWAS countries and the export value added (EVA) of these countries for 1990, 1995, 2000, 2005 and 2012, respectively. For most of these countries, the levels of FVA and the EVA are very low. However, Nigeria and countries such as Côte d'Ivoire, Ghana and, to a lesser extent, Senegal have an acceptable level of trade value added. For these countries, both foreign and domestic trade value added increased over the 1990-2012

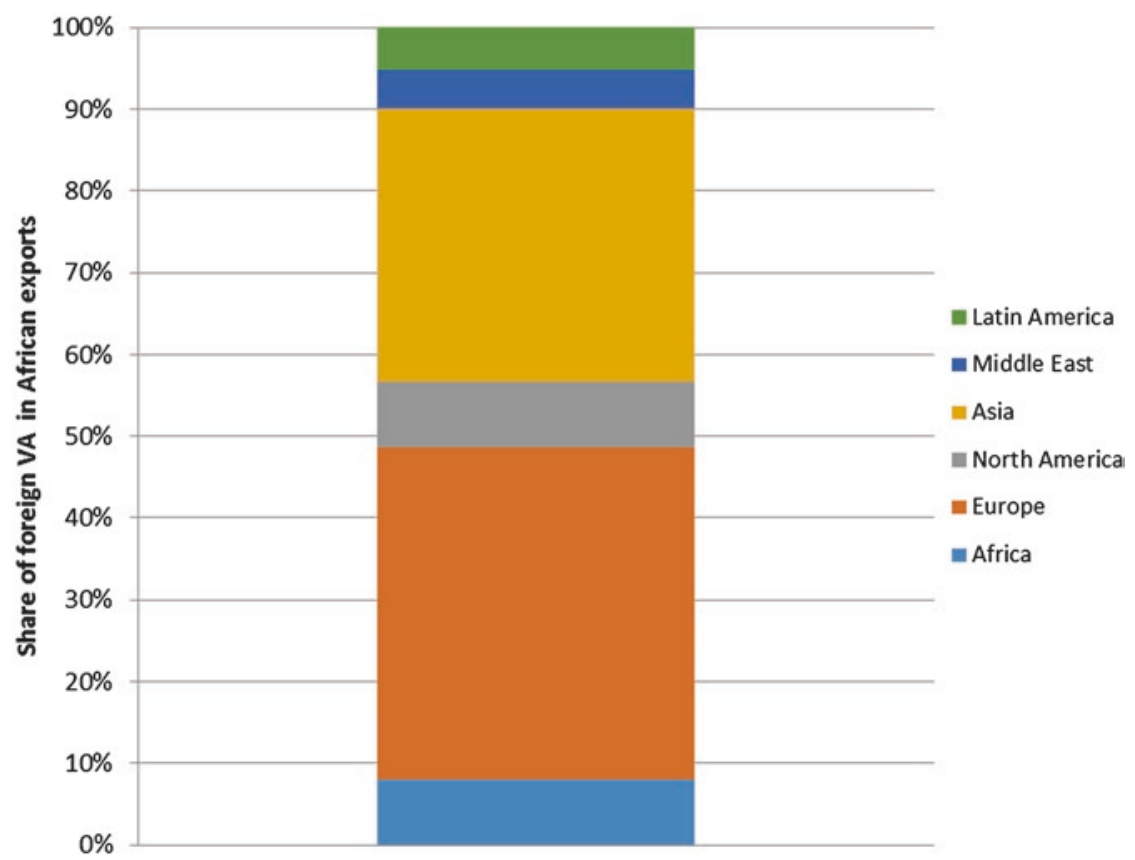

Fig. 12.2 Sources of intermediary products in West Africa. Source: Authors' elaboration based on AfDB et al. (2014) (based on UNCTAD-EORA-GVC data) 


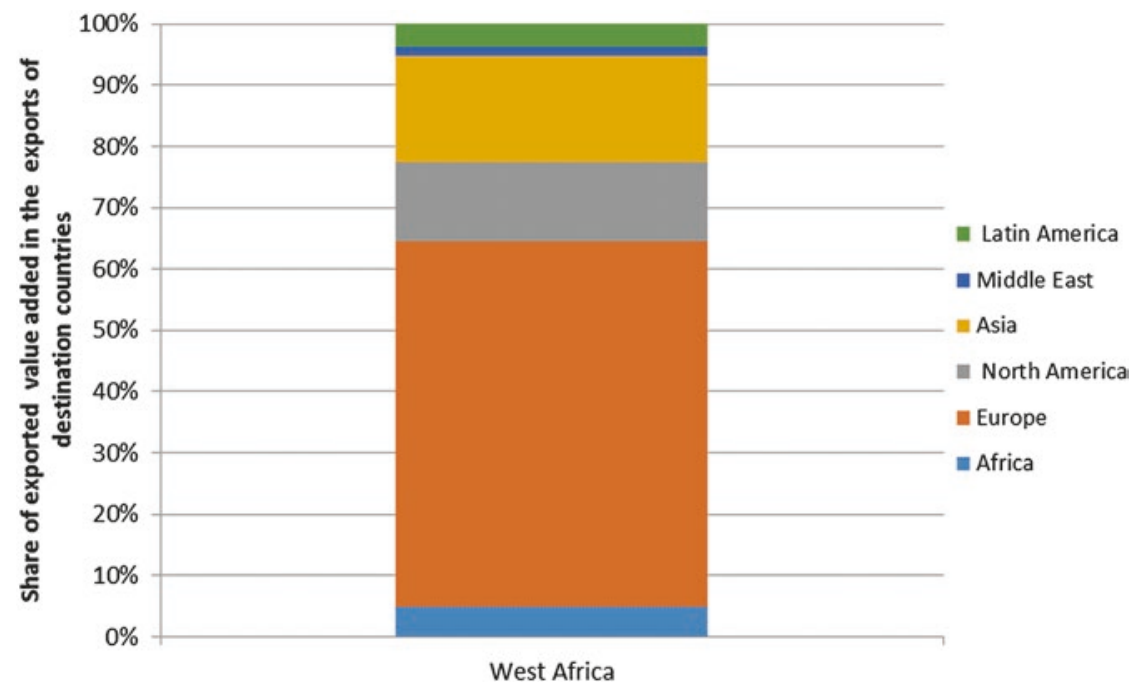

Fig. 12.3 Destinations of intermediary products in West Africa. Source: Authors' elaboration based on AfDB et al. (2014) (based on UNCTAD-EORA-GVC data)

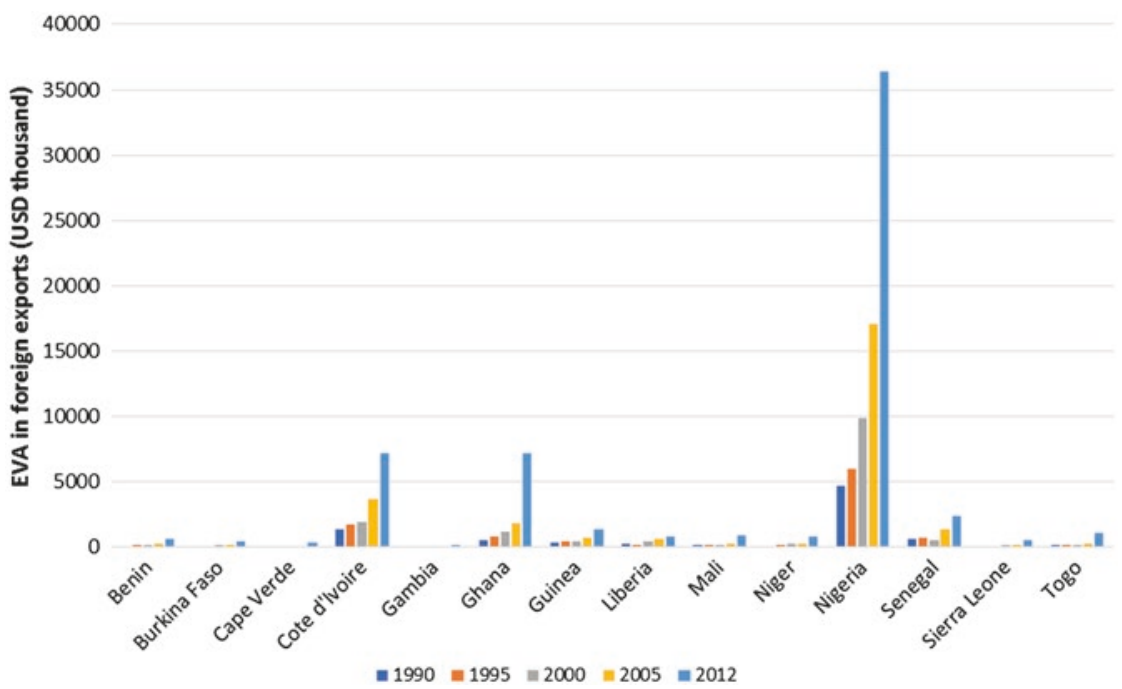

Fig. 12.4 EVA content of foreign exports (USD thousand). Souce: Authors' elaboration based on UNCTAD-EORA-GVC data 


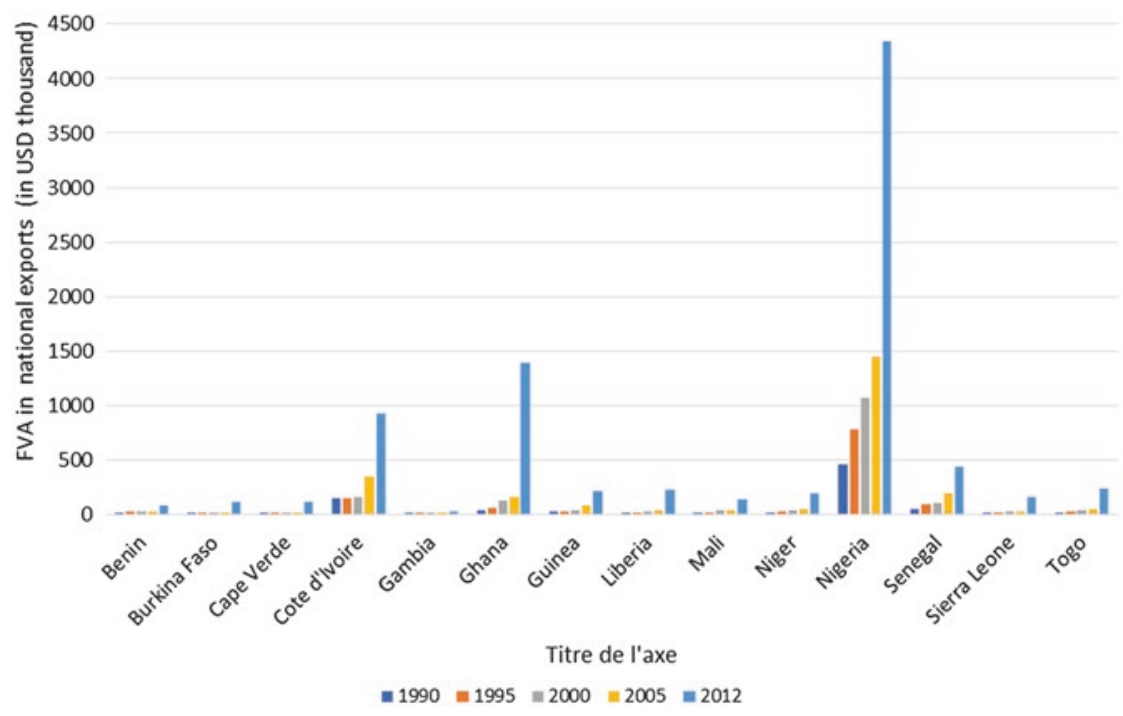

Fig. 12.5 FVA content of national exports (USD thousand). Source: Authors' elaboration based on UNCTAD-EORA-GVC data

period (for Nigeria, for example, the exported value added rose from about USD 5 million in 1990 to about USD 35 million in 2012, compared with the foreign value added which increased from USD $0.5 \mathrm{mil}$ lion to USD 4.5 million over the same period).

The average participation of West Africa in the GVC conceals disparities between member countries. Taken individually, the participation of ECOWAS countries in the GVC is very low, driven by a high level of forward integration. Guinea, Ghana and, to a lesser extent, Nigeria, are the most integrated countries downstream of the GVC, with integration levels of $41 \%, 32 \%$ and $30 \%$, respectively. In terms of backward integration, Togo, Sierra Leone, Ghana and Burkina Faso are the most integrated countries. Benin and Gambia are the least integrated countries in the community with a total integration level of $27 \%$ and $29 \%$, respectively (Fig. 12.6).

In short, this analysis shows that ECOWAS countries effectively participate in the GVC, but the participation is strongly driven by primary commodity exports, which may limit any possibility of upgrading in the GVC. 


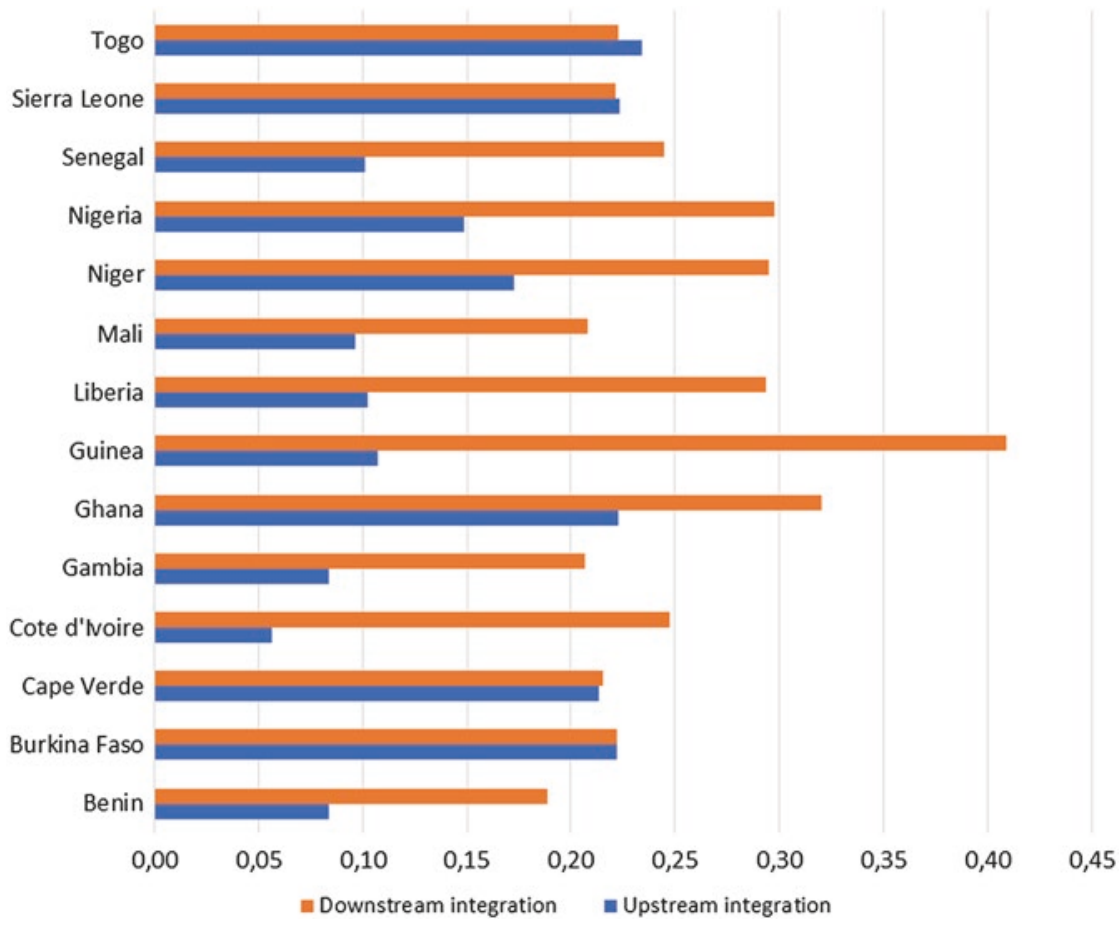

Fig. 12.6 Integration of ECOWAS countries in the GVC, 2011 (\%). Source: Authors' elaboration based on AfDB et al. (2014) (based on UNCTAD-EORA-GVC data)

\subsection{Upgrading of ECOWAS Countries}

\subsubsection{Mythological Data}

To analyse the different aspects of upgrading, we have used a number of indicators. We began by capturing the upgrading through the change in FVA content of a country's exports. Then we have adopted the approach used by Cottet et al. (2012) to capture the upgrading of diversification, sophistication and export base renewal indicators. 


\subsubsection{Indicator of the Foreign Value Added Content of Exports}

Here, we developed an approach which captures upgrading through increase in the FVA content of a country's exports. This indicator is given by:

$$
I_{\mathrm{FVA}}=\mathrm{FVA}_{t}-\mathrm{FVA}_{t-1}
$$

With $\mathrm{FVA}_{t}$ representing the foreign value added content of a country's exports at period $t$, and $\mathrm{FVA}_{t-1}$ being that for period $t-1$. When this indicator is positive, we may suspect that there is upgrading in the GVC.

\subsubsection{Traditional Diversification Indicators: The Hirschman Index}

The Hirschman index is one of the indices most commonly used to measure the weight of each sector in total exports (Cadot et al. 2013). According to this approach, the less a country depends on a limited number of export goods, the more it is considered diversified. Conversely, when a product accounts for a huge portion of a country's exports, the country is considered concentrated. This index is calculated as follows:

$$
H_{1}=\sqrt{\sum_{i=1}^{N}\left(\frac{x_{i}}{X}\right)^{2}},
$$

where $\left(x_{i}\right)$ denotes the value of the exports the good $i, X$ the total exports $\left(X=\sum_{i=1}^{N} x_{i}\right)$ and $N$ the number of product groups. It is then standardized for easier reading: 


$$
N H_{1}=\frac{H_{1}-\sqrt{\frac{1}{N}}}{1-\sqrt{\frac{1}{N}}}
$$

The NH value closest to 1 represents the highest concentration/lowest diversification and vice versa. When this indicator is equal to 1 , the country is entirely dependent on a single export product.

\subsubsection{Export Sophistication Measurement Indicator}

The capacity to incorporate technological content into exports is not limited to increasing the degree of diversification. This leads us to a new indicator for measuring the degree of exports sophistication. This indicator assesses the level of industrial exports as a share of the population (Cottet et al. 2012) and is calculated as follows:

$$
I_{\text {inndus }}=\frac{\sum_{i \in K} x_{i}}{\text { POP }},
$$

where $K$ denotes the subgroup of industrial products and POP, ${ }^{5}$ the country's population. This indicator isolates export products other than primary products (agricultural or extractive), which make up the bulk of a country's exports.

\subsubsection{Capacity to Export New Products: Extensive Margin and Intensive Margin}

A lot of publications break down export growth according to the appearance of new export lines (extensive margin) or according to the increase in the export of already existing products (intensive margin) (Melitz 2003). Depending on which margin dominates the other, export growth can stem from either diversification or specialization. Indeed, when the 
extensive margin dominates the intensive margin, the upgrading of products results in exports diversification (Cadot et al. 2011). On the other hand, when the intensive margin accounts for most of the exports, this may reflect specialization in the export base (Helpman et al. 2008).

However, the launch of new export products is not necessarily an end in itself, nor sufficient to ensure export diversification. The new products launched must therefore consolidate over time. We thus witness an alternation of diversification and concentration phases, causing the so-called Big Hits phenomena whereby export growth is driven by a few flagship products (Easterly and Reshef 2010).

The latter indicator, inspired by the works of Easterly and Reshef (2010) and Amiti and Freund (2010), breaks down export growth as follows:

$$
\frac{x_{t}-x_{t-1}}{x_{t-1}}=\frac{t_{t}-t_{t-1}}{x_{t-1}}+\frac{n_{t}-d_{t-1}}{x_{t-1}}
$$

where $\frac{t_{t}-t_{t-1}}{x_{t-1}}$, measures the intensive margin and $\frac{n_{t}-d_{t-1}}{x_{t-1}}$ the extensive margin. The intensive margin is measured by the increase in "traditional" exports (referred to as $t$ ) exported at two periods $t-1$ and $t$. The extensive margin is measured by the increase in new exports, or the difference between new exports $(n)$ at period $t$ and products that have disappeared from the exports $(d)$ since period $t-1$, with $\left(x_{t-1}\right)$ denoting total exports at period $t-1$, and $\left(x_{t}\right)$ the exports at period $t .^{6}$

To differentiate export flagship products from nascent products, we break down the intensive margin according to three types of goods ${ }^{7}$ : lowintensity export products $\left(t_{F}\right)$, medium-intensity export products $\left(t_{M}\right)$ and flagship export products $\left(t_{P}\right)$. The first account for less than $2 \%$ of the country's total exports, while the last represent between $2 \%$ and $10 \%$ of total exports and the last more than $10 \%$ of total exports. Our equation is thus rewritten as follows:

$$
\frac{x_{t}-x_{t-1}}{x_{t-1}}=\frac{t_{F_{t}}-t_{F_{t-1}}}{x_{t-1}}+\frac{t_{M_{t}}-t_{M_{t-1}}}{x_{t-1}}+\frac{t_{P_{t}}-t_{P_{t-1}}}{x_{t-1}}+\frac{n_{t}-d_{t-1}}{x_{t-1}}
$$


This breakdown of the intensive margin makes it possible to determine whether the export growth is due to the flagship products or rather the Big Hits phenomena.

UNCTAD's EORA-GVC (2014) database is used to analyse the FVA indicator of a country's exports, while the agency's Commodity Trade Statistics Database (Comtrade) and World Integrated Trade Solution (WITS) database are used to calculate the other indicators. Population data come from the World Bank's World Development Indicators (WDI) database.

\subsection{Results}

The results are presented according to the methodological approach. Thus, we first present the results of the EVA indicator followed by the diversification, sophistication and export base renewal indicators.

\subsubsection{Indicator of the Foreign Value Added Content of Exports}

In most ECOWAS countries, between 1995 and 2011, GVC growth occurred in tandem with the FVA of exports. We note that most countries are in the upper right quadrant, that is to say, they have increased the share of FVA content of their exports as well as the share of local value added content of exports relative to GDP. This suggests that from 1995 to 2011, upgrading in the GVC became more pronounced in most ECOWAS countries. (Fig. 12.7). It should be noted, however, that this indicator is not sufficient to characterize a country's upgrading in GVC, given that it does not allow for export diversification analysis.

\subsubsection{Traditional Indicators: Hirschman index}

The reading of this index (Annex 1) shows that ECOWAS countries are characterized by low diversification levels. Generally, most of the countries have highly concentrated goods exports, as shown by the diversification 


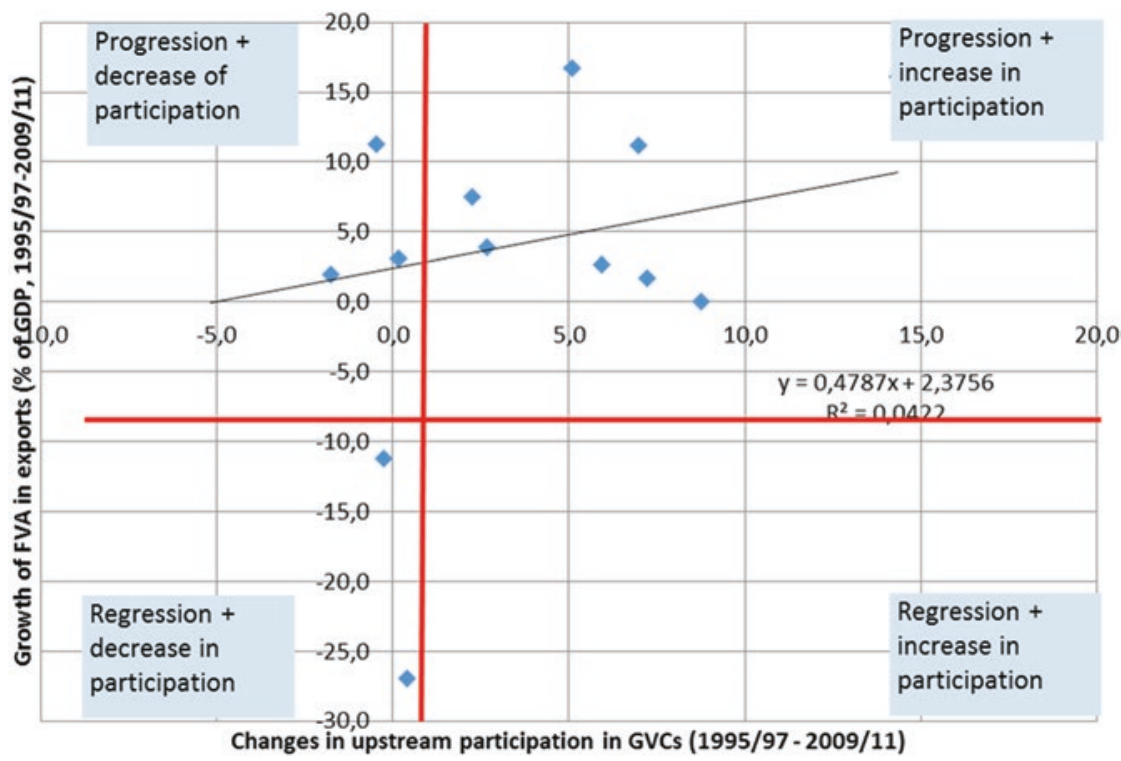

Fig. 12.7 Participation in GVC and growth of FVA in exports as a percentage of GDP, 1995/1997, compared with 2009/2011. Source: AfDB et al. (2014) (based on UNCTAD-EORA-GVC data)

index, which has an average value of more than 0.7 for all countries. These countries have therefore not been successful in upgrading by directing their conventional exports towards new, more dynamic and more promising sectors. Nigeria appears to be the most concentrated ECOWAS economy, with an average diversification index of 0.85 over the study period. This position enjoyed by Nigeria could be attributed to a strong concentration on oil export, which presumably makes up the lion's share of the country's exports.

Exports from all of these countries are highly concentrated on a limited number of low-tech products, which is confirmed by the statistics in the table provided in Annex 2. This table presents, for each country, the average share of the top five exported products, compared with total exports over the period 2010-2014. For all countries, the share of the leading export product in the total exports averages $47 \%$ and accounts for more than half of total exports in 5 of the $14^{8}$ ECOWAS countries for which data are available. In some countries, the largest export product 
dominates total exports (Guinea-Bissau: 96\%, Nigeria: 73\%, Mali: $72 \%)$. It is not less dominant in other countries such as Burkina Faso (52\%, Gold), Niger (50\%, Uranium) or Gambia (50\%, artificial filament fabrics). Togo, Senegal and Côte d'Ivoire are exceptions, with the share of their dominant export products accounting for less than $50 \%$ of total exports (or 16\%, 16\% and 23\% respectively).

In Benin, cotton, refined petroleum, cashew nut, rice and gold are the main export commodities over the period under review and account for about $54 \%$ of total exports. Gold, cotton, sesame seeds, cashew nuts and oilseeds are Burkina Faso's main export products and account for about $76 \%$ of total exports. The growth of mining activities in Burkina Faso, especially gold exports, is robust. Invigorated by new discoveries of deposits and a generous tax system designed to attract foreign investors, gold production represents $52 \%$ of the country's total exports between 2010 and 2014. In Côte d'Ivoire, a review of the diversification index (Annex 1) shows that the economy is also highly concentrated. Cocoa, oil and rubber were, on average, the most exported conventional products over the period 2010-2014. In Cape Verde, tuna is the leading export product, accounting for $34 \%$ of total exports. The five products exported during the period under review represented $84 \%$ of total exports, on average. Artificial filament fabric exports make up about $50 \%$ of total Gambian exports (the top five export products account on average for $61 \%$ of total exports). In Guinea-Bissau, the pattern of goods exports makes them highly concentrated on a single product. Raw cashew nuts remain the main export product, with an average share of about $96 \%$. Aluminium, gold, postage stamps and rubber account for $90 \%$ of Guinea's exports. Gold and cotton are the main exports of Mali and together account for $78 \%$ of total exports.

Uranium is Niger's traditional export product (50\%), with the top five exports estimated to make up $79 \%$ of the country's total exports. Oil represented, on average, $81 \%$ of Nigeria's exports between 2010 and 2014. In Sierra Leone, the range of exports consists mainly of tin, ethylene-vinyl acetate copolymer, packaging and cocoa husks, representing $87 \%$ of total exports. Oil, gold, phosphoric acid, cement and fresh fish make up $48 \%$ of Senegal's total exports. Togo is rich in mineral resources, which places the country at the forefront of economic diversification within the community. Cotton, cement and phosphate produc- 
tion was estimated at 39\% of total exports over the period 2010-2014 (see Annex 2). In summary, ECOWAS economies are characterized by an export pattern that is highly concentrated on natural resources, which confirms the results of the diversification index.

\subsubsection{Export Sophistication Measurement Indicator}

Table 12.1 shows that the level of sophistication is relatively low in ECOWAS countries, that is, their industrial exports level is low relative to the population size (compared with South Africa). Nevertheless, these countries do not form a homogeneous block of industrial product exporters. There are significant differences between these countries, which may be divided into two groups: (1) countries with the highest industrial export values relative to their populations (Ghana, Côte d'Ivoire, Nigeria, Cape Verde, Senegal, Niger, Togo and Sierra Leone) and (2) countries that export very insignificant or no industrial products (Guinea-Bissau, Gambia, Burkina Faso, Benin and Mali). These results confirm the low level of upgrading (functional upgrading and process upgrading) in ECOWAS countries, as their exports have very little technological value added. That is partly due to the fact that these countries have a low level of skilled labour, which limits all possibilities of technology transfer.

Table 12.1 Average level of industrial exports relative to population (in USD per capita) between 2010 and 2014

\begin{tabular}{lclc}
\hline Country & $\begin{array}{l}\text { Industrial exports/ } \\
\text { population }\end{array}$ & Country & $\begin{array}{l}\text { Industrial exports/ } \\
\text { population }\end{array}$ \\
\hline Benin & 4.93 & Mali & 6.17 \\
Burkina Faso & 2.06 & Niger & 29.63 \\
Cape Verde & 47.65 & Nigeria & 91.53 \\
Côte d'Ivoire & $222.12^{\mathrm{a}}$ & Senegal & 45.42 \\
Gambia & 1.39 & Sierra Leone & 15.12 \\
Ghana & $272.57^{\mathrm{a}}$ & Togo & 27.75 \\
Guinea-Bissau & 0.10 & South Africa & 377.12 \\
\hline
\end{tabular}

Source: UNCTAD and IMF, calculated by the authors

aRelatively more sophisticated 
The sophistication indicator can, however, be supplemented by analysis of the sub-sectors to which these products belong. The question is whether these products belong to new export lines or to existing ones.

\subsubsection{Capacity to Export New Products: Extensive Margin and Intensive Margin}

The low trade diversification level does not necessarily mean that the exported products are stable. One may witness the creation of new products, an upturn in the sector or a recomposition of the export base. Product upgrading in ECOWAS countries between the period 2000-2002 and 2012-2014 is analysed by breaking down the growth of exports into an intensive margin (increase in exports of traditional products) and an extensive margin (net creation of new export products). ${ }^{9}$ The results (Table 12.2) show a strong heterogeneity between countries. For some countries, the exports tripled (Côte d'Ivoire, Cape Verde, Guinea, Mali, Senegal and Togo), for others, they increased fivefold (Niger, Gambia, Nigeria) and even tenfold (Burkina Faso) and for others still, they doubled (Benin).

The exports from ECOWAS countries ${ }^{10}$ have experienced an average growth rate of about $350 \%$. The average extensive margin for these countries $(228 \%)$ is nearly twice as high as the intensive margin (122\%). The increase in exports is due, on average, more to the net creation of new exports than to an increase in traditional exports. However, this result changes once one begins reasoning in terms of the median levels: the median growth rate of these countries is about $250 \%$, with an extensive median margin of $114 \%$ and an intensive median margin of $131 \%$. In this case, the growth of exports would then be more dependent on the traditional products, which, therefore, means that there is no product upgrading.

A more detailed analysis of the results of the intensive margin shows that for most countries of the community (Benin, Burkina Faso, Côte d'Ivoire, Guinea, Mali, Nigeria, Senegal and Togo), growth is driven by moderately and intensely exported products. The main products (column g) are the most buoyant, except for'Togo, whose leading export (phosphate) 


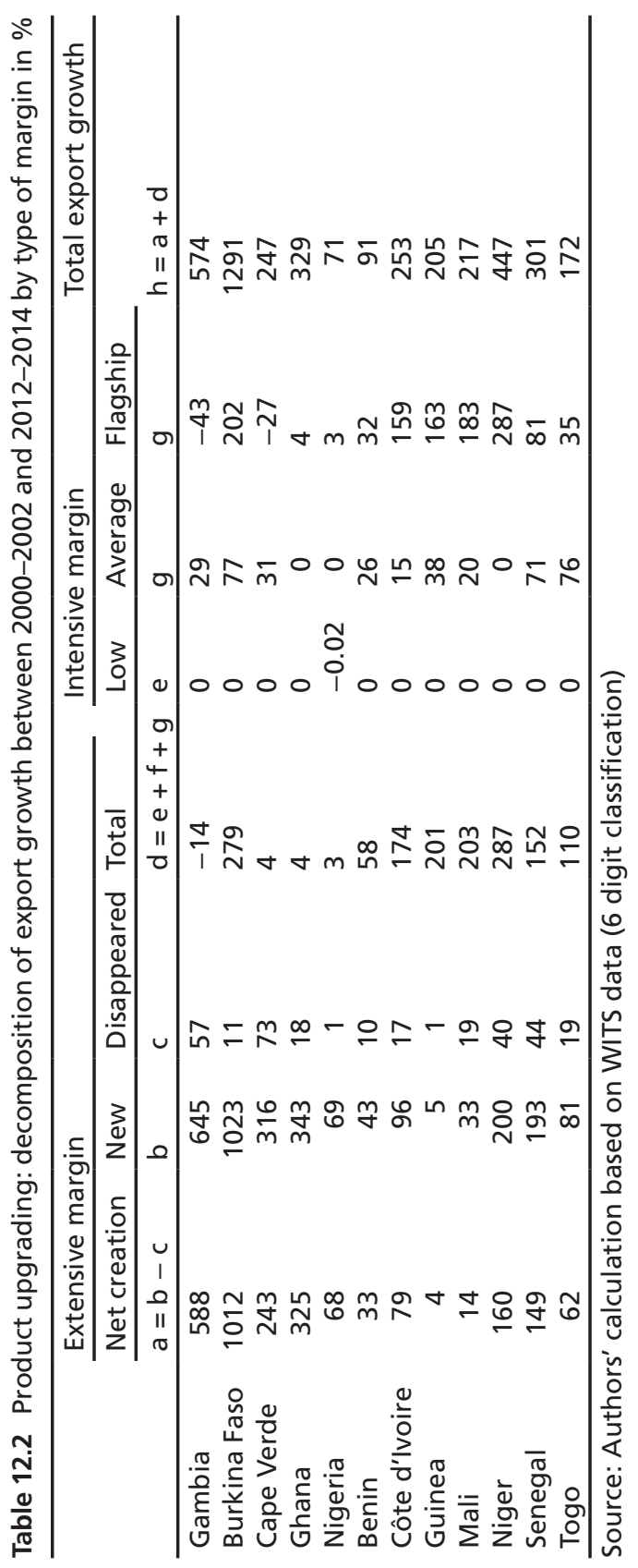


experienced a decline in favour of cotton, which was not as yet included among flagship products for the period 2000-2002. The intensive margin of low export products is virtually non-existent, with the exception of Nigeria, which has witnessed a decline in these products. This shows the difficulties that ECOWAS countries have in promoting and supporting their emerging exports in the medium and long term. This result goes to confirm the one obtained by Cottet et al. (2012) for franc-zone countries. Hausmann and Rodrik (2003) have also shown that least developed countries are finding it hard to overcome the barriers hindering the launch of new export lines.

An analysis of the results by country makes it possible to identify characteristics specific to each country or group of countries:

Product upgrading in Gambia was driven only by the extensive margin (column a). Indeed, the intensive margin for flagship exports (column g) experienced a sharp decline, reflecting the process of recomposition of this country's export base. Traditional export products (peanut and peanut oil) have indeed given way to new products (fabrics and cashew nuts).

The export growth experienced by Burkina Faso, Cape Verde, Ghana and Nigeria has been largely boosted by the increase in new products ( 412 percentage points on average for column a), and also by the intensive margin (column d), which contributed an average of 72.5 percentage points. However, Burkina Faso's export growth is much higher (1291 percentage points) than that of other countries (329 percentage points for Ghana, 247 for Cape Verde and 71 for Nigeria). Burkina Faso has witnessed an increase in the export of cotton (202 percentage points-column g), which has been the flagship export product since the colonial era. Despite this solid traditional base, Burkina Faso has evidently found a new export line brought about by the very rapid development of gold mining activity, reflecting an upturn in the sector. Gold production rose from a negligible volume in 2007 to almost 39 tonnes in 2013, or $71 \%$ of exports (IMF 2014)_enabling the extensive margin to contribute to the overall export growth to the tune of 1012 percentage points (column a).

The other countries (Benin, Côte d'Ivoire, Guinea, Mali, Niger, Senegal and Togo) have largely benefited from the increase in the intensive margin 
(169 percentage points on average), compared with 72 percentage points on average for the extensive margin, which, in actual fact, attests to the intensification process being undergone by traditional export products. Senegal, however, stands out from the other countries by dint of the relatively homogeneous distribution of the extensive margin (149 percentage points) and the intensive margin (152 percentage points). Thus, the country has succeeded in creating new export sectors which, in the medium term, have remained in the export base (as in the case of gold exports and Portland cement-see Annex 2).

\subsection{Conclusion}

The analyses in this chapter show that external trade in ECOWAS is characterized by a strong expansion trend (increase in exports and imports). Sustained demand for commodities has undoubtedly stimulated the development of trade, particularly with emerging countries. Even though ECOWAS trade has risen sharply, it remains below the potential of the region when it comes to positioning in the GVC.

The trade pattern shows a dependence on commodity exports, which is a barrier to better integration in the GVC. The participation of these countries in the GVC is strongly driven by the export of primary products, which has somewhat limited the chances of upgrading in the value chain. Even though some countries have managed to create new export lines, upgrading analysis (through diversification and sophistication indicators) shows that exports from ECOWAS countries are considered to be highly concentrated on a limited number of low-tech products.

The results of this study highlight the need for effective public intervention to improve the international competitiveness of these countries and promote new products abroad. This will involve investing in infrastructure and supporting export companies. To take advantage of their integration into the world economy, we recommend more backward integration for these countries in the GVC. We also believe that integration of national productions would capture more value added through the sophistication and diversification of production. 


\section{Annex 1}

Table 12.3 Diversification index of ECOWAS countries (1995, 2000, 2005, 2010 and 2014)

\begin{tabular}{llllll}
\hline & 1995 & 2000 & 2005 & 2010 & 2014 \\
\hline Benin & 0.77 & 0.81 & 0.79 & 0.75 & 0.76 \\
Burkina Faso & 0.80 & 0.75 & 0.82 & 0.83 & 0.76 \\
Cape Verde & 0.61 & 0.66 & 0.71 & 0.72 & 0.70 \\
Côte d'Ivoire & 0.82 & 0.81 & 0.73 & 0.73 & 0.74 \\
Gambia & 0.79 & 0.76 & 0.70 & 0.75 & 0.76 \\
Ghana & 0.83 & 0.81 & 0.82 & 0.79 & 0.75 \\
Guinea & 0.86 & 0.85 & 0.85 & 0.82 & 0.80 \\
Guinea Bissau & 0.69 & 0.67 & 0.66 & 0.76 & 0.77 \\
Liberia & 0.77 & 0.83 & 0.85 & 0.71 & 0.82 \\
Mali & 0.76 & 0.81 & 0.82 & 0.84 & 0.84 \\
Niger & 0.77 & 0.85 & 0.78 & 0.79 & 0.83 \\
Nigeria & 0.89 & 0.88 & 0.86 & 0.81 & 0.81 \\
Senegal & 0.81 & 0.77 & 0.69 & 0.76 & 0.73 \\
Sierra Leone & 0.71 & 0.66 & 0.68 & 0.69 & 0.86 \\
Togo & 0.74 & 0.75 & 0.72 & 0.72 & 0.69 \\
\hline
\end{tabular}

Source: UNCTAD database

\section{Annex 2}

Table 12.4 Share of the five leading exports products of ECOWAS countries in total exports (in \%; 2010-2014 average)

\begin{tabular}{lll}
\hline Share of leading products at less than $50 \%$ of total exports \\
\hline Country & Main products & Share in exports (\%) \\
\hline Benin & Cotton & 30 \\
& Refined oil & 9 \\
& Cashew nuts & 8 \\
& Rice (Ground) & 4 \\
& Gold & 3 \\
Côte d'Ivoire & Cocoa bean & 23 \\
& Refined oil & 14 \\
& Crude oil & 9 \\
& Rubber & 6 \\
& Sawn timber & 5 \\
\hline
\end{tabular}


Table 12.4 (continued)

\begin{tabular}{|c|c|c|}
\hline \multicolumn{3}{|c|}{ Share of leading products at less than $50 \%$ of total exports } \\
\hline Country & Main products & Share in exports (\%) \\
\hline \multirow[t]{5}{*}{ Cape Verde } & Thons & 34 \\
\hline & Prepared or preserved mackerel & 24 \\
\hline & Prepared or preserved fish & 13 \\
\hline & Shoe tops, other than leather & 7 \\
\hline & Fresh fish & 5 \\
\hline \multirow[t]{5}{*}{ Ghana } & Transformed gold & 33 \\
\hline & Crude oil & 18 \\
\hline & Cocoa beans & 12 \\
\hline & Butanes & 10 \\
\hline & Gold & 7 \\
\hline \multirow[t]{5}{*}{ Guinea } & Aluminium ores & 45 \\
\hline & Gold & 31 \\
\hline & Postage stamps, tax stamps and the like & 10 \\
\hline & Aluminium oxide & 3 \\
\hline & Rubber & 1 \\
\hline \multirow[t]{5}{*}{ Senegal } & Refined oil & 16 \\
\hline & Gold & 12 \\
\hline & Phosphoric acid & 9 \\
\hline & Portland cement & 8 \\
\hline & Fresh fish & 4 \\
\hline \multirow[t]{5}{*}{ Togo } & Cotton & 16 \\
\hline & Cement (clinker) & 9 \\
\hline & Portland cement & 7 \\
\hline & Phosphates & 7 \\
\hline & Make-up and skin care products & 4 \\
\hline \multirow[t]{5}{*}{ Burkina Faso } & Gold & 52 \\
\hline & Cotton (unginned) & 16 \\
\hline & Sesame seeds & 4 \\
\hline & Cashew nuts & 2 \\
\hline & Oilseeds & 2 \\
\hline \multirow[t]{5}{*}{ Gambia } & Artificial filaments fabrics & 50 \\
\hline & Cashew nuts & 4 \\
\hline & Clothing and other items to wear & 3 \\
\hline & Groundnut oil & 3 \\
\hline & Refined oil & 3 \\
\hline Guinea & Cashew nuts & 96 \\
\hline \multirow[t]{4}{*}{ Bissau } & Cranes & 1 \\
\hline & Cotton & 0 \\
\hline & Crude oil & 0 \\
\hline & Paper pulp & 0 \\
\hline
\end{tabular}


Table 12.4 (continued)

\begin{tabular}{llc}
\hline Share of leading products at less than 50\% of total exports \\
\hline Country & Main products & Share in exports (\%) \\
\hline Mali & Gold & 72 \\
& Cotton (ginned) & 6 \\
& Cotton (unginned) & 4 \\
& Mineral or chemical fertilizer (with & 3 \\
& nitrogen) & \\
& Mineral or chemical fertilizer (without & 2 \\
& nitrogen) & 50 \\
Niger & Uranium & 22 \\
& Crude oil & 3 \\
& Clothing and other items to wear & 2 \\
& Radioactive products & 2 \\
& Gold & 73 \\
Nigeria & Crude oil & 8 \\
& Refined oil & 5 \\
& Gas & 4 \\
& Rubber & 1 \\
& Cocoa beans & 73 \\
Sierra Leone & Tin & 11 \\
& Ethylene-vinyl acetate copolymer & 2 \\
& Articles for packaging of goods & 2 \\
& Cocoa shells & 1 \\
& Automobiles with reciprocating piston & \\
engine
\end{tabular}

Source: Authors' calculation based WITS data (HS classification)

\section{Notes}

1. According to the study entitled "Global Value Chains: Challenges, Opportunities and Implications for Policy".

2. A company undergoes upgrading in the GVC when it creates higher value added by moving away from low-tech activities (Gereffi et al. 2001).

3. Report of the African Centre for Trade, Integration and Development (ACACID), 2012.

4. AfDB et al. (2014).

5. The population is chosen instead of GDP because of the marked differences in the production pattern of ECOWAS countries. Oil producing countries have higher GDP per capita than others. 
6. $t-1$ covers the period 1990-1992 and $t$ corresponds to the period 2010-2012. This makes it possible to control the exceptional exports of new products and irregularities of declaration in the calculation of the extensive margin.

7. We drew inspiration from Cottet et al. (2012).

8. Data are not available for Liberia.

9. It may be said that the country is upgrading (product upgrading) if the extensive margin is wider than the intensive margin.

10. Those for which the data needed for calculation were available: Benin, Burkina Faso, Cap Vert, Côte d'Ivoire, Gambia, Ghana, Guinea, Mali, Niger, Nigeria, Senegal and Togo.

\section{References}

Abdon, A., \& Felipe, J. (2011). The Product Space: What Does it say About the Opportunities for Growth and Structural Transformation of Sub-Saharan Africa? AfDB, OECD, \& UNDP. (2014). African Economic Outlook. Paris: OECD Publishing.

Amiti, M., \& Freund, C. (2010). The Anatomy of China's Export Growth. In China's Growing Role in World Trade (pp. 35-56). University of Chicago Press.

Baldwin, D. A. (2012). Power and International. In W. Carlsnaes, T. Risse, \& B. A. Simmons (Eds.), Handbook of International Relations (pp. 273-297). London: Sage.

Baldwin, J. R., Yan, B., \& others. (2014). Global Value Chains and the Productivity of Canadian Manufacturing Firms. Statistics Canada.

Bernhardt, T., \& Milberg, W. (2011). Economic and Social Upgrading in Global Value Chains: Analysis of Horticulture, Apparel, Tourism and Mobile Telephones.

Cadot, O., Carrère, C., \& Strauss-Kahn, V. (2011). Export Diversification: What's Behind the Hump? Review of Economics and Statistics, 93(2), 590-605.

Cadot, O., Carrere, C., \& Strauss-Kahn, V. (2013). Trade Diversification, Income, and Growth: What Do We Know? Journal of Economic Surveys, 27(4), 790-812.

Cottet, C., Madariaga, N., \& Gou, N. J. (2012). La Diversification Des Exportations En Zone Franc: Degré, Sophistication et Dynamique. AFD, Macroéconomie et Développement, 3. 
Easterly, W., \& Reshef, A. (2010). African Export Successes: Surprises, Stylized Facts, and Explanations. National Bureau of Economic Research.

Escaith, H. (2014). Mapping Global Value Chains and Measuring Trade in Tasks. In B. Ferrarini \& D. Hummels (Eds.), Asia and Global Production Networks: Implications for Trade, Incomes and Economic Vulnerability. Cheltenham and Metro Manila: Asian Development Bank and Edwar Elgar Publishing.

Felipe, J., Kumar, U., Usui, N., \& Abdon, A. (2012). Why Has China Succeeded? And Why it Will Continue to Do So. Cambridge Journal of Economics, 37(4), 791-818.

Gereffi, G., \& Fernandez-Stark, K. (2011). Global Value Chain Analysis: A Primer. Center on Globalization, Governance \& Competitiveness (CGGC), Duke University, North Carolina, USA.

Gereffi, G., Humphrey, J., \& Kaplinsky, R. (2001). Introduction: Globalisation, Value Chains and Development. IDS Bulletin, 32(3), 1-8.

Hausmann R., \& Jasmina, C. (2015). Moving to the Adjacent Possible: Discovering Paths for Export Diversification in Rwanda. CID Working Paper No. 294, April.

Hausmann, R., \& Rodrik, D. (2003). Economic Development as Self-Discovery. Journal of Development Economics 72 (2): 603-633. Rapport du FMI No. $14 / 215$.

Hausmann, R., Cunningham, B., Matovu, J. M., Osire, R., \& Wyett, K. (2014). How Should Uganda Grow?

Helpman, E., Melitz, M., \& Rubinstein, Y. (2008). Estimating Trade Flows: Trading Partners and Trading Volumes. The Quarterly Journal of Economics, 123(2), 441-487.

Hidalgo, C. A. (2011). Discovering Southern and East Africa's Industrial Opportunities. Economic Policy Paper Series. The German Marshall Fund of the United States.

Humphrey, J. (2004). Upgrading in Global Value Chains. International Labour Office Working Paper.

Humphrey, J., \& Schmitz, H. (2000). Governance and Upgrading: Linking Industrial Cluster and Global Value Chain Research (Vol. 120). Brighton: Institute of Development Studies.

Kaplinsky, R. (2004). Spreading the Gains from Globalization: What Can Be Learnt from Value-Chain Analysis. Problems of Economic Transition, 47(2), 74-115. 
Koopman, R. (2011). Powers1 W., Wang, Z., Wei, SJ Give Credit to Where Credit Ls Due: Tracing Value Added in Global Production Chains [Z]. NBER Working Papers.

Lahille, É., Plichon, C., Vadcar, C., \& Weber, B. (1995). Les Principales Causes Des Délocalisations. In Au-Delà Des Délocalisations. Globalisation et Internationalisation Des Firmes, Chambre de Commerce et d'industrie de Paris, Collection «Entreprise et Perspectives Économiques». Economica.

Lorenzi, J. H. (2005). Mondialisation et nouvelle stratégie d'entreprise. Paris: Paris Dauphine University.

Lunati, M. (2008). Enhancing the Role of SMEs in Global Value Chains'. Staying Competitive in the Global Economy, 65.

Melitz, M. J. (2003). The Impact of Trade on Intra-Industry Reallocations and Aggregate Industry Productivity. Econometrica, 71(6), 1695-1725.

Porter, M. E. (1986). Changing Patterns of International Competition. California Management Review, 28(2), 9-40.

Porter, M. E., \& Competitive Advantage. (1985). Creating and Sustaining Superior Performance. New York: Free Press.

Rodrik, D. (2006). What's so Special About China's Exports? China \& World Economy, 14(5), 1-19.

Open Access This chapter is licensed under the terms of the Creative Commons Attribution 4.0 International License (http://creativecommons.org/licenses/ by/4.0/), which permits use, sharing, adaptation, distribution and reproduction in any medium or format, as long as you give appropriate credit to the original author(s) and the source, provide a link to the Creative Commons license and indicate if changes were made.

The images or other third party material in this chapter are included in the chapter's Creative Commons license, unless indicated otherwise in a credit line to the material. If material is not included in the chapter's Creative Commons license and your intended use is not permitted by statutory regulation or exceeds the permitted use, you will need to obtain permission directly from the copyright holder.

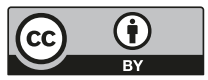

